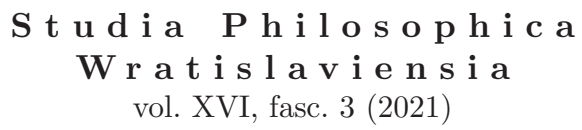

St ud i P hilosophic a

Wratis l avi e n s i a

vol. XVI, fasc. 3 (2021)

https://doi.org/10.19195/1895-8001.16.3.4

\author{
MARCIN GILETA \\ Uniwersytet Marii Curie-Skłodowskiej, Lublin \\ SEBASTIAN KOZERA \\ Uniwersytet Marii Curie-Skłodowskiej, Lublin
}

ANDRZEJ ŁUKASIK

ORCID: 0000-0001-9939-9135

Instytut Filozofii, Uniwersytet Marii Curie-Skłodowskiej, Lublin

\title{
Równania mądrzejsze od swych odkrywców
}

\section{Equations smarter than their discoverers}

\begin{abstract}
This article aims to critically analyse the concept of the development of science, as proposed by Wojciech Sady in the work Struktura rewolucji relatywistycznej i kwantowej w fizyce [The Structure of the Relativity and Quantum Revolution in Physics]. The author uses Ludwik Fleck's concept of thought styles and thought collectives to analyse the problem of how two great scientific revolutions took place in 20th-Century physics in terms of the rise of quantum theory and special relativity. Sady argues that the way of thinking of scientists is determined by the particular thought style in which they were educated, and that great scientific discoveries are not the result of "creative imagination", but a product of deductive reasoning, in which scholars closely adhere to the formalism of mathematical theory and the results of experiments. Therefore, scientific discovery in physics is made "on paper" rather than "in the mind of a scientist." In the "battle of equations with the imagination," equations always win, and scientific discovery is more a result of the work of a scientific community than solitary geniuses, and can only be made at the right time in history, called the "discoverygenic situation." The concept of the development of science presented in The Structure is directed against the incommensurability thesis and the indeterminacy thesis.
\end{abstract}

Keywords: scientific revolutions, Ludwik Fleck, Thomas Kuhn, thought collectives, thought styles, discoverygenic situation, paradigm incommensurability, indeterminacy 


\section{Uwagi wstępne}

Słynna wypowiedź Heinricha Hertza użyta jako tytuł niniejszego artykułu dobrze oddaje główną ideę zawartą w książce Wojciecha Sadego Struktura rewolucji relatywistycznej $i$ kwantowej $w$ fizyce ${ }^{1}$. Znajdujemy w niej intersującą próbę odpowiedzi na pytanie, jak doszło do dwóch wielkich rewolucji naukowych w fizyce XX wieku, związanych z powstaniem mechaniki kwantowej i teorii względności. Książka wyraźnie dzieli się na dwie warstwy — szczegółowe studium z historii nauki, oparte na bardzo bogatym materiale źródłowym oraz „komentarze”, w których znajdujemy rozważania z zakresu filozofii nauki, usiłujące ustalić mechanizmy odkryć naukowych, łącznie z tymi, które uznajemy współcześnie za najbardziej rewolucyjne. Przeprowadzone analizy pozostają pod głębokim wpływem koncepcji stylów myślowych i kolektywów myślowych polskiego mikrobiologa i filozofa nauki Ludwika Flecka (1891-1961). Nie miejsce oczywiście w niniejszym artykule na szczegółową prezentację filozofii nauki Flecka, tym bardziej że uczynił to Sady na kartach Struktury, a także w obszernym haśle „Ludwik Fleck” w Stanford Encyclopedia of Philoso$p h y^{2}$. Zauważmy jedynie, że zgodnie z koncepcją Flecka badania naukowe prowadzone są przez uczonych, którzy funkcjonują zawsze w ramach określonego kolektywu myślowego, a dla każdego kolektywu istnieje określony styl myślowy, który uczeni przyswajają sobie w procesie socjalizacji (pierwotnej i wtórnej), i który determinuje ich sposób postrzegania świata, wybór tematów badawczych i metodologii. Poznanie naukowe ma zatem na wskroś charakter społeczny: „Patrzymy oczami własnymi, ale widzimy oczami kolektywu"3, przy czym poszczególni uczeni na ogół nie mają świadomości swojego uwikłania w kolektywny styl myślenia, poza który nigdy nie są w stanie wykroczyć, a akceptowane na danym etapie rozwoju nauki teorie i modele traktują jak ,samą rzeczywistość”. Jeśli tak jest w istocie, to pojawia się pytanie, będące centralnym pytaniem książki Sadego: ,jeśli przyswojony system warunkuje działalność badawczą, podsuwa tematykę badań i narzuca sposoby ich prowadzenia, to jak to możliwe, aby uczeni zaczęli myśleć inaczej, niż ich myśleć nauczono? W szczególności, jak to się stało, że — wbrew przymusom myślowym narzucanym przez mechanikę klasyczną — wymyślono teorię względności i mechanikę kwantową?"4.

Sady koncepcje „samotnego geniusza”, „wymyślania śmiałych hipotez” czy też „wyobraźni twórczej” traktuje jako mity fałszywie przedstawiające historię nauki. Na kartach książki wielokrotnie pojawia się teza, że „co nie może zdarzyć się w umy-

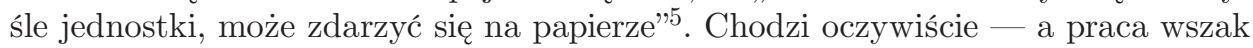
poświęcona jest historii i filozofii fizyki — o fundamentalne znaczenie dla rozwoju fizyki równań matematycznych i wyników eksperymentów, a nie towarzyszących im poglądowych wyobrażeń, które na ogół nie wniosły niczego nowego do teorii,

\footnotetext{
1 W. Sady, Struktura rewolucji relatywistycznej i kwantowej w fizyce, Kraków 2020.

2 W. Sady, Ludwik Fleck, [w:] The Stanford Encyclopedia of Philosophy, https://plato.stanford. edu/entries/fleck/.

3 W. Sady, Struktura rewolucji relatywistycznej i kwantowej w fizyce, s. 21.

4 Ibidem, s. 26.

5 Por. ibidem, s. 141.
} 
a nawet stanowiły przeszkodę epistemologiczną w rozwoju nauki. Z licznych przykładów podanych w Strukturze wspomnimy jedynie „deformujący wpływ wyobraźni" ${ }^{\prime}$ na badania Maxwella i jego próby przedstawienia sobie fal elektromagnetycznych jako drgań sprężystego eteru, w odróżnieniu od znaczenia równań matematycznych, stanowiących podstawę elektrodynamiki klasycznej i wnoszących trwały wkład w rozwój fizyki. W historii nauki przejawia się — zdaniem Sadego „walka logiki z wyobraźnią”. To równania matematyczne i logika przyczyniają się do rozwoju nauki, a nie wyobrażeniowe modele, które okazują się zwykle zbędnym dodatkiem. Równania, eksperymenty i logika, a także właściw y c z as jest zdaniem autora Struktury niezbędny do odkrycia naukowego: „Odkrycia można dokonać tylko wtedy, gdy stan wiedzy zwerbalizowanej do tego dojrzeje”7, co Sady za Elżbietą Pietruską-Madej określa mianem ,sytuacji odkryciogennej"8. Rozwój nauki ma zasadniczo charakter kumulatywny, na żadnym etapie nie dochodzi do zerwania z tradycją — ,zarówno szczególna teoria względności, jak i mechanika kwantowa były wytworami prac prowadzonych krok po kroku przez wspólnotę badaczy"9. Odkrycia naukowe nie są rezultatem wyobraźni twórczej genialnych jednostek, lecz są wy wnioskow ane z zastanej wiedzy przez odpowiednio do tego przygotowanych uczonych, którzy ponadto znaleźli się w odpowiedniej sytuacji odkryciogennej ${ }^{10}$. Nikt nie może „wyprzedzić czasu epoki” i wykroczyć poza styl myślowy determinujący sposób myślenia uczonego — w nauce można jedynie eksperymentować i wnioskować na podstawie równań opisujących zjawiska.

\section{Rewolucja relatywistyczna}

W Strukturze znajdujemy krytyczną ocenę poglądów wielu filozofów nauki i poglądów filozofujaccych fizyków. Poglądy Karla Poppera i przedstawicieli Koła Wiedeńskiego określa Sady jako „naiwne”. Jako przykład przedstawia nakreśloną w duchu popperowskim historię falsyfikacji teorii klasycznych i zastąpienia ich przez teorie relatywistyczną oraz kwantową zamieszczoną w książce Istota i struktura $f i z y k i^{11}$ fizyka Leona Coopera, laureata Nagrody Nobla. Problem w tym, że przedstawione przez Coopera opisy — na przykład cel eksperymentu Michelsona-Morleya, czy teoria Plancka jako reakcja na „katastrofę w nadfiolecie” - mijają się z prawdą historyczną. Miesza on chronologię zdarzeń, aby pasowała do rozpowszechnionej wśród uczonych naiwnej interpretacji mechanizmów rozwoju nauki ${ }^{12}$. Podobny zarzut Sady kieruje w stronę Thomasa Kuhna, który pisząc o rewolucji kopernikańskiej, ignoruje czternaście wieków rozwoju astronomii między Ptolemeuszem a Kopernikiem, co pozwala doszukiwać się niewspółmierności między systemem

6 Ibidem, s. 82.

7 Ibidem, s. 177.

8 Por. Odkrycie naukowe i inne zagadnienia współczesnej filozofii nauki. Pamięci Elżbiety Pietruskiej-Madej i Jana Żytkowa, W. Krajewski, W. Strawiński (red.), Warszawa 2003.

9 W. Sady, Struktura rewolucji relatywistycznej i kwantowej w fizyce, s. 209.

10 Por. ibidem, s. 214.

11 L.N. Cooper, Istota i struktura fizyki, tłum. J. Kozubowski et al., Warszawa 1975.

12 Por. W. Sady, Struktura rewolucji relatywistycznej $i$ kwantowej $w$ fizyce, s. 11. 
Ptolemeusza a systemem Kopernika tak, jakby między tymi systemami nic się nie działo w astronomii ${ }^{13}$. W obu więc przypadkach — Coopera i Kuhna - mamy do czynienia ze zniekształceniem historii nauki.

Autor twierdzi, że tak samo jak dziecko uczące się poznawania świata potrzebuje otoczenia (socjalizacja pierwotna), tak też naukowcy nie mogą prowadzić swych badań w oderwaniu od wspólnoty naukowej (socjalizacja wtórna). Powołuje się na poglądy Flecka ${ }^{14}$, który wśród społeczności uczonych wyróżnił „krąg ezoteryczny” oraz „krąg egzoteryczny”. Ten pierwszy składa się z ,awangardy”, czyli wybitnych badaczy, „grupy zasadniczej”, czyli naukowców rzetelnie wykonujących swą pracę oraz „maruderów”. Krąg egzoteryczny jest znacznie liczniejszy — to ludzie interesujący się nauką i korzystający z rezultatów pracy kręgu ezoterycznego. Praca badaczy ma być możliwa do odtworzenia dla kolegów po fachu, a ich poglądy religijne, polityczne czy związane z pochodzeniem nie mogą rzutować na poglądy naukowe. Krąg ezoteryczny nie zamyka się na świat, wręcz przeciwnie — popularyzuje zdobytą wiedzę, przekazując ją szerszym masom stanowiącym krąg egzoteryczny. Naukowcy wreszcie mają na względzie motywy utylitarystyczne — polepszenie jakości życia ludzkości jest często traktowane jako priorytet. Taki opis wydaje się być nieco wyidealizowany. Analogia między socjalizacją pierwotną a socjalizacją wtórną przyszłego naukowca obejmuje również brak precyzyjnie sformułowanych zasad dziecko uczy się języka poprzez obserwację i naśladownictwo i dokładnie tak samo jest na poszczególnych etapach rozwoju naukowego badacza. Gramatycy w pierwszym i filozofowie nauki w drugim przypadku próbują takie zasady określić, jednak nie są one potrzebne, by nabyć określone umiejętności.

Następnie Sady charakteryzuje programy badawcze w obrębie fizyki. Opierają się one na założeniu, że zmiany w świecie fizycznym, zachodzą na mocy niezmiennych praw. Te prawa odpowiednio zastosowane powinny utworzyć teoretyczny opis pokrywający się z wynikami eksperymentów. Tak powstają odkrycia naukowe, które zsumowane stanowią rdzeń fizycznego obrazu świata. Taki obraz świata ma pewne luki, które czynią go programem badawczym. Zadaniem naukowców jest pozbycie się tych obszarów niewiedzy. Do luk zaliczają się błędy w wynikach eksperymentów oraz przybliżenia przy wykonywaniu obliczeń. Najważniejsze w badaniach jest dołączanie kolejnych odkryć do programu badawczego. Kryterium naukowości badań jest według autora systematyczność. Polega ona według niego na tym, że rozpoczyna się analizę od zjawisk najprostszych, a potem kolejno przechodzi się do coraz bardziej złożonych. Poza tym istotne jest również przeprowadzanie dużej liczby doświadczeń w jak najróżniejszych warunkach. Można wysunąć pewne wątpliwości, czy sama systematyczność badań jest wystarczającym kryterium naukowości,

13 Por. T.S. Kuhn, The Structure of Scientific Revolutions, Chicago 1962 (wyd. polskie: Struktura rewolucji naukowych, tłum. H. Ostromęcka, Warszawa 1968).

14 Por. L. Fleck, Enstehung und Enwicklung einer wissenschaflicjen Tatsache: Einführung in der lehre von Denkstil und Denkkolektiv, Basel 1935 (wyd polskie: Powstanie i rozwój faktu naukowego: wprowadzenie do nauki o stylu myślowym i kolektywie myślowym, tłum. M. Tuszkiewicz, Lublin 1986); L. Fleck, Psychosocjologia poznania naukowego. Powstanie i rozwój faktu naukowego oraz inne pisma z teorii poznania, tłum. W.A. Niemirski, Z. Cackowski, S. Symotiuk (red.), Lublin 2006. 
ale nie jest to główny wątek rozwijany w Strukturze, zatem „problem demarkacji” zostanie pominięty.

Sady formułuje pytanie, będące celem dociekań jego książki: jak to jest możliwe, że doszło do rewolucji relatywistycznej i kwantowej, skoro naukowcy byli zanurzeni w systemie narzucającym konkretne założenia, metody badawcze i sposoby myślenia, które wydawałoby się, uniemożliwiałyby tak znaczącą zmianę percepcji świata? Autor, w celu odpowiedzi na to pytanie dokonuje opisu przemian obrazu świata na przestrzeni wieków. Rozpoczyna od opisu świata mechaniki klasycznej. Stosując ontologię w sensie Quine'a, można powiedzieć, że na obraz świata mechaniki klasycznej składają się cztery elementy: absolutna przestrzeń, absolutny czas, ciała oraz siły. Sady zwraca uwagę na pewne rozdwojenie występujące w czasach Newtona — z jednej strony nierozwiązany problem sił działających na odległość, który został temporalnie odsunięty na bok, z drugiej strony dobrze opisane siły działające przez kontakt. Ontologia mechaniki klasycznej powiększyła się za sprawą prac Coulomba, dzięki którym własności materii wzbogacona zostały o ładunki elektryczne i własności magnetyczne.

Autor krytycznie podchodzi do poglądu (podzielanego między innymi przez Poppera), że nie istnieje coś takiego, jak logika odkrywania. Zdaniem wielu filozofów nauki nowe teorie i hipotezy nie mogą być wynikiem wniosków na mocy dedukcji czy indukcji. Potrzebny jest geniusz, wychodzący poza ramy danego systemu, intuicja i twórcza wyobraźnia potrafiąca uchwycić to, co niedostępne za pomocą rozumowania w ramach dotychczasowego paradygmatu. Sady odpiera taką interpretację analizą odkrycia Coulomba o odwrotnej proporcjonalności sił działających między ładunkami elektrycznymi do kwadratu odległości między nimi. Dochodzi do wniosku, że rozumowanie fizyka było dedukcyjne, bowiem wywodziło się z szeregu założeń wynikających z praw mechaniki oraz wyników eksperymentów samego Coulomba. Następnie wskazuje, że zaszło indukcyjne uogólnienie na więcej przypadków uwzględniających również siły magnetyczne. Natomiast ówczesna „,twórcza wyobraźnia” w wykonaniu fizyków nie przyniosła żadnych rezultatów i stanowi dla nas jedynie ciekawostkę - jako przykład można podać pogląd, że wielu uczonych sądziło, iż elektryczność jest płynem o określonych własnościach.

Sady następnie opisuje historię zmagań uczonych w ramach mechanicznej falowej teorii światła. Po raz kolejny okazuje się, że bieg wydarzeń nie pokrywa się z filozofią nauki w wydaniu Kuhna. Nie dochodzi bowiem do poważnego kryzysu i niepokoju naukowców wobec pojawiających się kolejno anomalii oraz błędnych hipotez ad hoc, wymyślanych, by wyjaśnić ,,anomalie”. Problematyczne kwestie są drugorzędne wobec piękna zakładanej teorii. Poza historyczną niezgodnością, Sady krytycznie odnosi się również do terminologii stosowanej przez Kuhna — słowo ,anomalia” może być uzasadnione jedynie z perspektywy czasów późniejszych, ówcześni badacze nie wiedzieli bowiem, czy napotkali na zagadnienie falsyfikujące teorię, czy też na odkrycie nowego faktu. Problem występuje również z „hipotezą ad hoc”. Nie są określone warunki odróżnienia hipotezy ad hoc od „zwykłej” hipotezy. Większość prac naukowych nie sprawdza żadnej hipotezy czy teorii, tylko służy przede wszystkim powiększeniu wiedzy. Rzeczywiście, wydaje się, że występuje tu podobny problem, co z ,anomaliami” — propozycje badaczy radzenia sobie z danymi problemami w ob- 
rębie jakiejś teorii, które okażą się błędne, zostają z punktu widzenia przyszłości zaklasyfikowane jako ad hoc. Jeżeli natomiast okazują się poprawne, to hipoteza uznawana jest za naukową.

W dalszej części swych rozważań autor wskazuje na pewien wpływ filozoficznych poglądów na odkrycia fizyczne. Na przykład zarówno Ørsted (przy odkryciu sił między prądami elektrycznymi a magnesami), jak i Ritter (przy odkryciu promieni nadfioletowych) przeprowadzali swoje badania na gruncie przekonania o jedności przyrody, wynikającego z zafascynowania romantyczną filozofią Schellinga (nota bene jest to jedna z nielicznych uwag dotyczacych wpływu przekonań filozoficznych uczonych na ich badania naukowe). Jednak naukowcy ci działali zgodnie z zasadami ówczesnej fizyki, a ponadto ich egzotyczną terminologię uczeni zastąpili językiem fizyki klasycznej i właśnie w takim stylu osiągnięcia te zostały uwiecznione. Jednakże bez takich, a nie innych poglądów filozoficznych tej dwójki naukowców nie prowadziliby oni swych badań w określony sposób, czyli wpływ poglądów filozoficznych uczonych na rozwój nauki w tym przypadku wydaje się bezsprzeczny.

Teza Sadego o kluczowej roli naukowego obrazu świata w percepcji badacza znajduje swoje potwierdzenie przy analizie odkryć z zakresu elektromagnetyzmu. Przykładem jest zignorowanie przez Ampere'a indukowania prądów, które później zostało opisane przez Faradaya. Najwyraźniej nie był to „odpowiedni czas” na to odkrycie i dopiero po kilku latach wzmożonej pracy badaczy na polu poszukiwań takiego zjawiska doszło do adekwatnych obserwacji. Poza Faradayem niezależnie i prawie w tym samym czasie dwójka innych naukowców doszła do tego odkrycia (Zantedeschi, James), co świadczy o nieuch ronności dostrzeżenia indukcji elektromagnetycznej w tamtych czasach.

Następnie wykazana jest rozbieżność między racjonalnym wyborem programu badawczego według Lakatosa a naukowymi decyzjami Maxwella. Autor zauważa, że wcale nie musi być tak, że za zmianą teorii mają przemawiać żelazne argumenty, sama motywacja bowiem nie decyduje o poprawności przyszłych badań. W przypadku Maxwella uwagi, które czynił pod adresem programu Fechnera i Webera, nie były precyzyjne i co gorsza były błędne. Mimo to osiągnął wielki sukces w swoich badaniach. Nie wydarzył się on jednak szybko. Sady opisuje pierwsze, bezowocne, próby, podkreślając po raz kolejny zawodność „twórczej wyobraźni”. Powodzenie zagwarantowała matematyka, która jak określa to autor: ,przezwyciężyła deformujący wpływ wyobraźni"15. Rozumowanie Maxwella miało charakter dedukcyjny, a jego punktem kulminacyjnym było następujące twierdzenie: wirowe pole magnetyczne jest wytwarzane zarówno przez zmienne pole elektryczne, jak i przez prąd elektryczny, a wirowanie następuje w płaszczyźnie prostopadłej do kierunku zmian pola elektrycznego i kierunku przepływu prądu. Według Sadego był to punkt zwrotny w historii fizyki i początek rewolucji relatywistycznej. Powodem, dla którego udało się „obejść” obraz świata dyktowany przez mechanikę klasyczną, było wyprowadzenie na papierze ze znanych równań kolejnych równań. Język matematyki zaprowadził badacza w rejony, których on nie mógł sobie (za sprawą ograniczającego społecznego systemu myślowego) wyobrazić (podobny pogląd wydaje się podzielać

15 W. Sady, Struktura rewolucji relatywistycznej i kwantowej w fizyce, s. 82. 
Michał Heller, on również wspominał o tej wykraczającej poza ograniczoną ludzką intuicję roli matematyki) ${ }^{16}$. Mimo że sam Maxwell ciągle rozpatrywał swoje badania w kontekście mechaniki, jego równania wskazały na tworzenie się nowego programu badawczego.

Odkrycia Maxwella nie były z początku powszechnie zaakceptowane. Autor wskazuje na zbyt zawiłą matematykę zawartą w pracach fizyka jako jeden z powodów. Jako przykład małej popularności tych badań w Niemczech przytaczany jest fakt, iż wydana tam wpływowa, obszerna praca o historii elektryczności z 1884 roku nawet słowem nie wspomina o Maxwellu. Z czasem jednak jego program badawczy został ogólnie przyjęty. Wiązało się to jednak ze społecznym zapotrzebowaniem na telegraf bez drutu, którego opracowanie wymagało elektrodynamiki Maxwella, a nie z racjonalnymi kryteriami wyboru teorii naukowej, które tak starają się ustalić filozofowie nauki.

Za twórcę szczególnej teorii względności powszechnie uznawany jest Einstein. Sady słusznie podkreśla jednak znaczenie prac Lorentza i Poincarégo, co jest często pomijane (zwłaszcza w pracach o charakterze popularnonaukowym) i znaczenie sytuacji odkryciogennej. Pojawia się tu intrygujacce pytanie: a co, gdyby Einsteina nie było? Koncepcja rozwoju nauki przedstawiona w Strukturze prowadzi do wniosku, że identyczna teoria zostałaby sformułowana przez innego uczonego, ponieważ w nauce nie ma niezastąpionych uczonych, a w określonych sytuacjach pewne odkrycia stają się nieuchronne ${ }^{17}$.

\section{Rewolucja kwantowa}

Sady korzeni rewolucji kwantowej w fizyce dopatruje się już w teoriach na temat ciepła, które zaczęły się pojawiać pod koniec XVIII wieku. Początkowo powodzeniem cieszyła się teoria cieplika, na podstawie której Sadi Carnot, Emile Clapeyron i William Thomson rozwinęli teorię silników cieplnych. Eksperymenty nad tarciem prowadzone między innymi przez Benjamina Thomsona coraz wyraźniej wskazywały jednak na związki ciepła z jakimiś formami ruchu. Około roku $1840 \mathrm{w}$ wyniku badań nad ciepłem sformułowana została zasada zachowania energii. Jak podkreśla Sady, odkrycie tej zasady było wynikiem pracy wielu fizyków, wśród których co prawda na wyróżnienie zasługują Mayer, Joule i Helmholtz, ale właściwym odkrywcą była cała wspólnota badaczy. Sam proces dochodzenia do sformułowania tej zasady był zaś bardzo złożony i trudny dziś do prześledzenia. Na początku XIX stulecia odkryto linie absorpcyjne najpierw w widmie Słońca a następnie w szeregu substancji dostępnych na Ziemi. Badania absorpcji i emisji światła przez różne substancje doprowadziły Kirchhoffa do rozważania warunków równowagi między energią emitowaną a absorbowaną. To zaś doprowadziło do zapostulowania istnienia zależności nazwanej później funkcją Kirchhoffa, a także do nakreślenia warunków eksperymentalnych w celu jej wyznaczenia. Kirchhoff zaproponował użycie cia-

16 Por. M. Heller, S. Krajewski, Czy fizyka i matematyka to nauki humanistyczne?, Kraków 2014, s. 226.

17 Por. W. Sady, Struktura rewolucji relatywistycznej i kwantowej $w$ fizyce, s. 120. 
ła doskonale czarnego, które pochłania całe padające na niego promieniowanie bez względu na temperaturę i zakres długości fali.

Jak wiadomo, równania mechaniki klasycznej są niezmiennicze względem inwersji w czasie. Badania nad ciepłem doprowadziły jednak do odkrycia procesów, które odwracalne nie są. Opierając się na pracach Thomsona, Clausius w roku 1865 sformułował II zasadę termodynamiki. Wprowadził też pojęcie entropii. Ostatecznie I i II zasada termodynamiki oznaczały, że 1. energia wszechświata jest stała i 2. entropia wszechświata dąży do maksimum.

Badania chemików dowiodły, że pierwiastki tworzą związki chemiczne, łącząc się w stałych stosunkach wagowych, co prowadziło w naturalny sposób do myśli o atomistycznej budowie materii sformułowanej przez Daltona. Z chemicznego obrazu świata atomy, jak ujmuje to Sady, zaczęły „przenikać” do obrazu fizycznego. Jeszcze w pierwszej połowie XIX wieku fizycy podejmowali próby opisu zjawisk termodynamicznych w wykorzystaniem teorii kinetycznej. Próby te prowadziły do wniosku, że temperatura jest proporcjonalna do średniej energii kinetycznej ruchu cząstek.

Badania nad ciepłem i światłem, jak zauważa Sady, wiąże to, że mimo, iż zjawiska cieplne i świetlne nie przedstawiają się w oczywisty sposób jako zjawiska polegające na ruchu cząstek, bądź fal w materialnym ośrodku, to od początku ich badania wyobraźnia naukowców zajmujących się tymi zjawiskami była niejako zniewolona mechanistycznym postrzeganiem świata, opartym oczywiście na mechanice newtonowskiej. Pojęcia ciepła i temperatury nie występowały jednak w mechanicznym opisie zjawisk. Dopiero po sformułowaniu zasady zachowania energii i po tym jak zaczęto posługiwać się teorią kinetyczno-molekularną termodynamika zyskała pewny grunt na polu mechaniki.

Wraz z rozwojem teorii cząsteczkowej gazów w fizyce zaczęła pojawiać się coraz częściej statystyka. Początków rachunku prawdopodobieństwa można szukać już w pracach Pascala, później zaczął być używany między innymi w astronomii i kryminalistyce, by zostać przez Maxwella z powodzeniem wykorzystany do opisu ruchu cząstek gazu. Statystyczne techniki Maxwella przejął i udoskonalił Ludwig Boltzmann. Korzystając z rachunku prawdopodobieństwa otrzymał rezultaty, które dowodziły, że złożenie dużej liczby procesów odwracalnych prowadzi do procesu nieodwracalnego. Pojawił się tu jednak paradoks zauważony przez Loschmidta: jeśli układ mechaniczny dąży do stanu równowagi, to po odwróceniu strzałki czasu powinien dążyć do stanu przeciwnego, czego w przyrodzie nie obserwujemy i czego nie opisuje teoria Boltzmanna oparta przecież na mechanice Newtona. Być może właśnie tutaj pojawił się pierwszy ślad kryzysu, który w pełni objawił się w latach dwudziestych XX wieku. Rachunek prawdopodobieństwa w sposób naturalny wiąże się z wielkościami dyskretnymi (na przykład zdarzenia takie jak rzut monetą), a zatem Boltzmann w swych rachunkach posługiwał się pewnym chwytem. Zakładał, że cząsteczki mają energię równą wielokrotności pewnej stałej energii, a następnie sprowadzał tę stałą, niewielką wartość energii w granicy do zera, otrzymując ciągły rozkład energii cząstek. Niedługo później Planck, korzystając z aparatu matematycznego Boltzmanna, zastosował podobny chwyt, tyle że niejako w odwrotnym kierunku.

Ostatnie trzy dziesięciolecia XIX wieku to między innymi bardzo intensywne badania nad promieniowaniem ciała doskonale czarnego, zarówno eksperymentalne 
jak i teoretyczne. Badania te były prowadzone przez wielu fizyków i postępy były wynikiem pracy całej w spólnoty uczonych. Pod koniec XIX wieku Ernst Zermelo argumentował, że opierając się tylko na mechanice klasycznej nie można uzasadnić istnienia procesów nieodwracalnych. Max Planck jednak podejmował próby uzasadnienia procesów nieodwracalnych, odwołując się do teorii elektromagnetycznej Maxwella. Początkowo zwalczając statystyczne wyjaśnienia procesów formułowane przez Boltzmanna, zaczął posługiwać się jego aparatem matematycznym korzystając z metod statystycznych. Na przełomie XIX i XX wieku, przy założeniu, że energia może być emitowania i absorbowana w porcjach zależnych od częstotliwości promieniowania Planck wyprowadził wzór na funkcję Kirchhoffa, która doskonale zgadzała się z danymi eksperymentalnymi. Jak zauważa Sady, w pismach Plancka z tego okresu nie ma wzmianki o tym, że doszło do wprowadzenia rewolucyjnej koncepcji naukowej.

Rozwój fizyki, który doprowadził do pierwszych wzorów kwantowych, jest zdaniem Sadego doskonałym potwierdzeniem jego tezy, że co prawda kompetencje naukowców i ich metody pracy są wynikiem pierwotnej i wtórnej socjalizacji, to jednak z chwilą pojawienia się kompletnych przesłanek, logika odkrycia zaczyna działać niezależnie od woli naukowców i niemal nieubłaganie prowadzi (głównie na drodze dedukcyjnej) do nowych odkryć. Intuicja i wyobraźnia twórcza jednostek mogą być dobrymi motywami pracy badawczej, ale nie mają koniecznego, określonego związku z osiągniętymi rezultatami. Równie dobrze mogą być przeszkodą w osiąganiu wyników, jak okazywać się zgodne z nowymi odkryciami, które to odkrycia sac jednak rezultatem wspólnej pracy badawczej całego środowiska naukowców, pracującego w ramach określonego stylu myślowego. Postęp dokonuje się, gdy sytuacja, dzięki zgromadzonym danym, dojrzeje do odkrycia. Sady zdaje się z jednej strony twierdzić, że rozwój wiedzy w sprzyjających warunkach przebiega niemal automatycznie, ale jednak przyznaje, że twórczy czynnik ludzki polegający choćby na łączeniu przesłanek wywodzących się z różnych programów badawczych ma również ważny wpływ.

Rozpoczęte w pierwszej połowie XIX wieku i prowadzone intensywnie badania nad promieniowaniem, któremu nadano nazwę promieniowania katodowego, prowadziły do sprzecznych wniosków co do natury tego promieniowania. Ścierały się z sobą dwie teorie. Jedna głosiła, że promieniowanie katodowe ma naturę korpuskularną a druga, że falową. Co ciekawe badania nad promieniami katodowymi przybrały charakter międzynarodowej rywalizacji. Uczeni angielscy opowiadali się za teorią korpuskularną a uczeni niemieccy obstawali przy falowej. Na marginesie można zauważyć, że Sady opisuje rywalizację miedzy Anglią a Niemcami w sposób, który mógłby sugerować, że dzięki owej rywalizacji i wzajemnym zwalczaniu argumentów przeciwników, badania nad naturą promieni katodowych zyskały dodatkową dynamikę.

Okrycie promieniowania X oraz promieniotwórczości naturalnej w samej końcówce wieku XIX jest przedstawione na tle analizy ówczesnego stanu badań i prowadzi do wniosków, że ów stan był tak dojrzały do tych odkryć, że wcześniej czy później musiało do nich dojść.

Pod koniec XIX wieku J.J. Thomson ostatecznie wyjaśnił naturę promieni katodowych, tym samym stając się dla przyszłych pokoleń odkrywcą elektronu. Sady 
zaznacza, że Thomson swoje badania prowadził najczęściej będąc motywowany przez wyobrażenia, które z perspektywy czasu okazały się zupełnie błędne. Przełom wieków to również odkrycie promieniowania alfa, efektu fotoelektrycznego i szeregu zjawisk, których jak się później okazało fizyka klasyczna nie jest w stanie w poprawny sposób opisać. Wówczas jednak, gdy zjawiska te były odkrywane, naukowcy, którzy tych odkryć dokonywali prowadzeni byli mechanistyczną wizją fizycznej rzeczywistości i kierowali się zasadami fizyki klasycznej. Sady podkreśla, że za wszystkimi odkryciami stała cała w s póln ot a ba d a c zy. Postrzeganie historii nauki jako dzieła nielicznych geniuszy, to skrajne uproszczenie dokonywane z perspektywy czasu.

W 1905 roku Einstein po raz pierwszy powiązał rezultaty prac Plancka związane z badaniem promieniowania ciała doskonale czarnego z wynikami badań nad promieniowaniem katodowym. Sady i tutaj zauważa, że dwa lata wcześniej Thomson zwrócił uwagę na to, że potraktowanie promieni X jako strumienia cząstek pozwala wyjaśnić jonizację gazów przez promieniowanie rentgenowskie.

Mimo że kwantowej teorii światła nikt początkowo nie traktował poważnie, Einstein w 1907 roku przedstawił artykuł, w którym przedstawił kwantową teorię ciepła właściwego, wyjaśniający zależność ciepła właściwego od temperatury.

Bez żadnych odwołań do idei kwantowych, opierając się jedynie na fizyce klasycznej Rutherford, prowadząc badania nad rozpraszaniem cząstek alfa, odkrył jądro atomowe (1911). Sady porównując styl pracy Rutherforda i Thomsona po raz kolejny określa to jako ,walkę logiki z wyobraźnią", dodając, że spekulatywne pomysły dostarczane Thomsonowi przez jego twórczą wyobraźnię okazywały się najczęściej błędne, gdy natomiast prace Rutherforda okazały się praktycznie wolne od błędów. Rutherford bowiem, zdaniem Sadego, bardziej przypomina systematycznego, dobrze wykształconego rzemieślnika niż genialnego wizjonera. Dochodzi do wyników wyłącznie na podstawie zastanego stanu wiedzy i danych eksperymentalnych drogą dedukcyjną, nie pozwalając sobie na porywy wyobraźni. Podobnie Sady tłumaczy brak sukcesów Einsteina w jego ostatnich 25 latach życia, kiedy to nie ograniczał się jedynie do wyciągania wniosków z dostępnych danych, jak to czynił w pierwszej fazie swojej naukowej kariery, ale pozwalał sobie na spekulacje i grę wyobraźni.

Od czasu odkrycia elektronu podejmowano najrozmaitsze próby stworzenia modelu atomu, włączając w to również elementy teorii kwantów. Udaną próbę można jednak przypisać Nielsowi Bohrowi, który w 1913 roku zaproponował model atomu wodoru. Sytuacja Bohra i jego odkrycia była, zdaniem Sadego, doskonałym przykładem sytuacji odkryciogennej. Bez wątpienia Bohr był niezwykłym naukowcem, ale wszystkie elementy, które były potrzebne do stworzenia modelu atomu nazywanego dziś jego imieniem, były już przez społeczność naukowców dostarczone. Tych elementów w postaci możliwych teorii i hipotez było nawet za wiele. Odkrycie w tych warunkach polega nie tyle na odkrywaniu czegoś rewolucyjnie nowego, ile na wybieraniu tego, co przygotowali inni członkowie środowiska naukowego (można się jednak w tym miejscu zastanawiać, czy wbrew argumentom Sadego nie mamy tu jednak do czynienia ze swego rodzaju momentem twórczym, zależnym od wyobraźni odkrywcy). Kiedy się już tego wyboru dokonało, reszta okazywała się jego logiczną konsekwencją. Potrzebny był tylko młody umysł, który nie był tak silnie zniewolony dotychczasowymi wyobrażeniami, jak naukowcy dojrzali, starsi, którym 
trudniej wyzwolić się spod wpływów obowiązującej wizji rzeczywistości (stylu myślowego - w terminologii Flecka).

Jednym z głównych wniosków Sadego z przeprowadzonych w książce analiz, o którym wprost pisze, jest zaprzeczenie tezom Kuhna o niewspółmierności paradygmatów. Różnice między nimi mogą jawić się jako niezwykle istotne, ale wrażenie to pojawia się tylko wówczas, gdy porównujemy okresy bardzo odległe od siebie w czasie. Przyglądając się jednak bliżej historii nauki, stwierdzić należy, i jest to inne sformułowanie wniosku Sadego, że w każdym momencie badacze czerpali z dotychczasowego stanu wiedzy zarówno eksperymentalnej, jak i teoretycznej, wcale nie próbując zerwać z tradycją. A jeśli nawet zachodziło w pewnym sensie owo zerwanie to niejako mimochodem i nigdy w sposób totalny. Często też bez woli, a nawet wiedzy badaczy, którym przypisywano rewolucyjne odkrycia. Badania na polu fizyki klasycznej na drodze dedukcyjnej prowadziły zatem do wniosków, które potem stawały się przesłankami w fizyce relatywistycznej i kwantowej. Wiele też pojęć i obiektów, które były efektem odkryć fizyki klasycznej, jak częstotliwość promieni X, masa i ładunek elektronu, weszły do obrazu świata tworzonego później przez fizykę kwantową i relatywistyczną. Proces wyłaniania się idei miał zatem proces ciągły, choć prawdopodobnie nie dotyczyło to recepcji owych idei przez społeczność naukową.

Odkrycie naukowe następuje w sytuacji odkryciogennej, to znaczy w sytuacji, w której społeczność badaczy zgromadzi tak dużo danych na temat pewnego zbioru zjawisk, że nieuniknione wydaje się wyciągniecie niemal narzucajacych się w tej sytuacji wniosków i sformułowanie odkrywczego spostrzeżenia. To wyjaśnia, dlaczego niejednokrotnie tego samego odkrycia dokonywało wielu naukowców w tym samym czasie. Nawet jeśli słusznie i jednoznacznie możemy przypisać odkrycie danemu uczonemu, to sytuacja odkryciogenna warunkująca to odkrycie jest dziełem całej wspólnoty naukowej.

W świetle tego, co zostało powiedziane, w naturalny sposób rodzi się pytanie: czy rozwój nauki jest zdeterminowany? W książce znajdujemy odpowiedź, że w pewnych okolicznościach tak. Stan nauki musi być jednak na określonym poziomie, z którego w pewnym sensie nie ma powrotu. Sady zatem odrzuca tezę o niedookreśleniu teorii, która pojawia się u Lakatosa. Zastrzega jednak, że dotyczy to fizyki dojrzałej. Oczywiście niezwykle ciekawym problemem byłoby ustalenie, jakie to cechy musi mieć nauka, czy też czym musi charakteryzować się jej stan, aby pojawił się ów poznawczy determinizm.

Twierdząc, że w różnych paradygmatach powstają niewspółmierne teorie naukowe, Kuhn musiał przyjąć, że zwycięstwo jednego paradygmatu nad drugim dokonuje się ostatecznie przez wymieranie starszego pokolenia naukowców związanego z wcześniej obowiązującym paradygmatem. Z tym Sady się nie zgadza. Wymiana pokoleń jest potrzebna ponieważ jest po prostu potrzebny czas, aby mogły zajść głębokie, ale systematyczne zmiany. Zarówno Kuhn, jak i Sady zdają się upatrywać w tym, że genialni naukowcy najczęściej w młodym wieku dokonywali najważniejszych odkryć przyczynę ich większej otwartości na nowe pomysły. Młody wiek miałby być warunkiem większej swobody wobec obowiązującego obrazu świata, co ułatwiałoby akceptację sprzecznych z tym obrazem rozwiązań. 
To, co było w istocie rewolucyjne, pojawiało się w rozwoju fizyki w postaci rów nań matematycznych i wynikało z innych równań. Rewolucje w fizyce dokonywały się zatem dzięki matematyce. Tu jako ilustrację Sady przypomina historię odkryć Maxwella, Plancka, Lorentza i innych, którzy, jak to określa autor, proces swoich odkryć przeprowadzili raczej „na papierze”, a nie „w głowie”. Tu również można się zastanawiać, czy taka rola matematyki pojawia się tylko w wyjątkowych okresach dojrzałej fizyki, kiedy już zgromadzono bardzo dużo danych, czy tė̇ jest, albo powinna być, obecna w całym procesie poznawczym na pierwszym planie (matematyczność rzeczywistości byłaby jakąś podstawową prawdą lub z jakiegoś powodu podstawowym narzędziem poznawczym). Sady przekonuje też, że w okresie, kiedy na „naukowym rynku idei” pojawia się wiele teorii i narzędzi badawczych, wyboru między nimi nie determinują żadne racjonalne reguły. Po prostu sprawdza się, co będzie pasować do danych.

Na zakończenie Sady dzieli się swoim rozumieniem prawdy w nauce. Otóż prawdziwe są tylko poszczególne twierdzenia i to w relacji do założeń, natomiast system jako całość do rzeczywistości się nie odnosi. Prawda do systemu nie ma jako taka zastosowania. Czy takie rozumienie prawdy i swego rodzaju globalny antyrealizm pomaga zrozumieć poznawczy determinizm dający się zauważyć, zgodnie z treści książki, w fizyce nowożytnej?

\section{Matematyka i eksperymenty a wyobraźnia}

W Strukturze czytamy, że, nie da się wyprzedzić swego czasu, wypełnić luk w naszej wiedzy wytworami wyobraźni. W nauce należy postępować krok za krokiem — również [...] w okresach rewolucyjnych — za każdym razem twierdzić tylko tyle, ile wynika z zastanej wiedzy i rezultatów eksperymentów"18. Czy taką regułę metodologiczną można uznać za ogólnie ważną? Nasuwają się pewne wątpliwości. W książce wielokrotnie pojawia się sformułowanie „matematyka kontra wyobraźnia”19. Czym jest „matematyka", to znaczy matematyczne równania występujące w teoriach fizycznych, jest dość oczywiste - chociaż Sady unika metafizycznych pytań o status ontologiczny przedmiotów matematyki i problemu matematyczności przyrody. Ale jak rozumiana jest „wyobraźnia”? Lektura książki, w szczególności zaś podawane przykłady „tworów wyobraźni” wiązanych z teoriami fizycznymi, pozwala stwierdzić, że termin „wyobraźnia” jest rozumiany niezwykle wąsko, a mianowicie jako określenie poglądowego, wyobrażeniowego mechanicznego modelu zjawisk, o których mowa w teorii. To, że dla uczonych XIX i początków XX wieku ,zrozumieć zjawisko" oznaczało „zbudować jego mechaniczny model”, jest powszechnie znane. Jednak jeżeli szerzej rozumieć „wyobraźnię”, nie ograniczając zakresu tego terminu do czysto mechanicznego obrazu zjawisk, wówczas wiele tez zawartych w Strukturze budzi pewne wątpliwości. Wyobrażać sobie można bowiem nie tylko wirujące pierścienie eteru, ale i obserwatora podążającego za promieniem świetlnym, czło-

18 W. Sady, Struktura rewolucji relatywistycznej $i$ kwantowej $w$ fizyce, s. 34.

19 Por. ibidem, s. 71. 
wieka znajdującego się w spadającej swobodnie windzie, układ dwóch cząstek, które oddziaływały z sobą i znajdują się w stanie splątanym, a następnie rozdzieliły się i poruszają się w przeciwne kierunki przestrzeni... Wiele z „wyobrażeń”, które opisują fizycy, które odegrały istotną rolę w rozwoju nauki, nie ma nic wspólnego z przedstawianiem sobie mechanicznych modeli zjawisk i odgrywa ważną rolę heurystyczną w budowaniu teorii, wy przedzają cą jakiekolwiek równania i wyniki eksperymentów. Wiele elementów wyobrażeniowych funkcjonuje nadal w metaforycznych modelach teoretycznych, takich jak na przykład planetarny model atomu Bohra czy model kolorowych kwarków Gell-Manna.

Pogląd Sadego ponadto osobliwie kontrastuje z twierdzeniami wielu wybitnych fizyków dotyczącymi roli (twórczej) wyobraźni w badaniach naukowych. Istotną rolę wyobraźni i intuicji podkreślał na przykład Einstein ${ }^{20}$. O swojej drodze do szczególnej teorii względności Einstein pisał następująco:

Coraz bardziej wątpiłem w możliwość odkrycia prawdziwych praw przez próby ich konstruowania w oparciu o znane fakty. Im dłużej i z większym uporem próbowałem, tym bardziej dochodziłem do przekonania, że do poprawnych wyników może doprowadzić tylko odkrycie uniwersalnej zasady formalnej ${ }^{21}$.

Kto zatem lepiej wie, czym się kierował Einstein — Sady czy Einstein? Sady twierdzi, że obraz mechanizmów rozwoju wiedzy rozpowszechniony wśród uczonych jest niewiarygodny i relacje uczonych o tym, jak dokonali odkryć (co oczywiście dotyczy nie tylko Einsteina) to „wymyślanie historii nauki wstecz, tak aby pasowała do naiwnego, a rozpowszechnionego wśród naukowców, obrazu mechanizmów rozwoju wiedzy"22. Faktem jest, że większość rewolucyjnych odkryć w fizyce została sformułowana przez bardzo młodych uczonych, a większość pism filozoficznych (w tym autobiograficznych), a także popularnonaukowych, w których piszą oni o swych odkryciach, powstała po kilkudziesięciu latach od tych odkryć i niekoniecznie tok myślenia, którym, jak sądzi uczony, dawniej się kierował, jest dokładnie taki, jakim się faktycznie kierował. Problem w tym, że nie dysponujemy metodami rozstrzygnięcia tego pytania. Jeśli chodzi o samego Einsteina, to ma on pełną świadomość problemu:

O ile państwo pragną nauczyć się czegoś od fizyków teoretyków o stosowanych przez nich metodach, proponuję, abyście kierowali się następującą zasadą: nie słuchajcie ich słów, lecz trzymajcie się ich czynów. Temu bowiem, kto coś wymyślił, wytwory własnej wyobraźni wydają się tak dalece konieczne i naturalne, że nie może ich już uznać za twór myśli, lecz widzi w nich istniejącą naprawdę rzeczywistość i pragnie, żeby i inni to samo widzieli ${ }^{23}$.

Sady twierdzi, że filozofia nauki fizyków jest zwykle naiwna. Interesujące jest, że wielu filozofujących fizyków wyraża negatywne stanowisko właśnie wobec filozofii nauki. Na przykład Weinberg argumentuje przeciw filozofii, twierdząc, że uczo-

20 Por. np. Albert Einstein. Pisma filozoficzne, tłum. K. Napiórkowski, S. Butrym (red.), Warszawa 1999, s. XXVII.

21 A. Einstein, Zapiski autobiograficzne, tłum. J. Bieroń, Kraków 1996, s. 33.

22 W. Sady, Struktura rewolucji relatywistycznej i kwantowej w fizyce, s. 11.

23 A. Einstein, O metodzie fizyki teoretycznej, [w:] idem, Jak wyobrażam sobie świat. Przemyślenia i opinie, tłum. T. Lanczewski, Kraków 2017, s. 371. 
nym nie pomaga ona w badaniach naukowych, co parafrazując Eugene Wignera, nazywa „niezrozumiałą nieskutecznością filozofii” ${ }^{24}$. Hawking twierdzi, że dziś „filozofia jest martwa”25, a Feynman pisał o „filozofach kawiarnianych”26, co również trudno uznać za pozytywną ocenę pracy filozofów. Jeśli istotnie w historii nauki przejawia się „walka matematyki z wyobraźnią”, to współcześnie daje się również zaobserwować (przynajmniej w odniesieniu do zagadnień związanych z filozofią nauki) „walka fizyków z filozofami”. Zagadnienie samo w sobie interesujące i warte dokładniejszych analiz.

Wydaje się, że pogląd prezentowany przez Sadego deprecjonuje w pewnej mierze rolę eksperymentów myślowych w fizyce. Eksperymenty myślowe odegrały jednak niewątpliwie pozytywną rolę w nauce, a są one przecież produktem c zystej wyobraźni. Galileusz nie obserwował ciał spadających w próżni i obserwować ich nie mógł, ponieważ w jego czasach uczeni nie potrafili jeszcze wytworzyć próżni. Spadek swobodny mógł sobie jedynie wyobrazić. Newton w yobrażał sobie wiadro wypełnione wodą, wirujące w pustej przestrzeni kosmicznej, czego - rzecz jasna - obserwować nie mógł. Einstein w yobrażał sobie, że podąża za promieniem światła z prędkością $c$, co prowadziło do paradoksalnego wniosku, że obserwator „powinien promień jako nieruchome, przestrzennie oscylujące pole elektromagnetyczne" 27 . Einstein w yobrażał s obie również, że znajduje się w spadającej windzie, czego oczywiście nie doświadczył, a ten eksperyment myślowy doprowadził go do sformułowania zasady równoważności, będącej podstawą ogólnej teorii względności (nazywał go „najszczęśliwszą myślą w życiu”). Zapewne gdyby nie Einstein, to szczególna teoria względności i tak zostałaby sformułowana, ponieważ stan fizyki na początku XX wieku do tego „dojrzał”. W tym przypadku można zgodzić się z Sadym. Znacznie trudniej w jego schemat rozwoju nauki wpisać sformułowanie ogólnej teorii względności — w tym przypadku nie było żadnych eksperymentów, na których mógł się oprzeć, a przewidywane przez nią fale grawitacyjne zostały wykryte doświadczalnie ponad sto lat po publikacji teorii. Trudno przecenić również znaczenie takich eksperymentów myślowych, jak EPR, kot Schrödingera i wielu innych dla naszego rozumienia mechaniki kwantowej (łącznie z superpozycją stanów, nielokalnością i kwantową teleportacją). Eksperymenty myślowe to jednak eksperymenty przeprowadzone wyłącznie w wyobraźni (oczywiście przy założeniu, że wszystko przebiega zgodnie ze znanymi prawami fizyki, chociaż rezultat eksperymentu rzeczywistego może okazać się niezgodny z oczekiwaniem jego pomysłodawcy, czego najlepszym dowodem jest Einsteinowskie „upiorne działanie na odległość", jeden z najbardziej zdumiewających rezultatów mechaniki kwantowej).

Rozwój fizyki prowadzi do sformułowania praw i teorii opisujących coraz rozleglejszy obszar doświadczenia. Prawa te — jak pisał Richard P. Feynman:

24 S. Weinberg, Sen o teorii ostatecznej, tłum. P. Amsterdamski, Warszawa 1994, s. 137.

25 S. Hawking, L. Mlodinow, Wielki projekt, tłum. J. Włodarczyk, Warszawa 2017, s. 9.

26 R.P. Feynman, Sześć trudniejszych kawałków. Teoria względności Einsteina, symetria i czasoprzestrzeń, tłum. P. Amsterdamski et al., Warszawa 1999, s. 109.

27 A. Einstein, Zapiski autobiograficzne, s. 33. 
mają jedną dziwną cechę - im wzrasta ich ogólność, tym stają się odleglejsze od zdroworozsądkowych przekonań i intuicyjnie mniej zrozumiałe. [...] Musimy maksymalnie wytężać wyobraźnię, nie po to odwrotnie niż w literaturze, wyobrazić sobie rzeczy, których naprawdę nie ma, ale by zrozumieć to, co naprawdę istnieje $\mathrm{e}^{28}$.

Wiadomo na przykład, że świat atomów i cząstek elementarnych opisywany przez formalizm matematyczny mechaniki kwantowej całkowicie wykracza poza nasze poglądowe wyobrażenia i nawet takie podstawowe pojęcia, jak „cząstka” i ,fala” muszą być rozumiane jedynie metaforycznie, to jednak te mechaniczne wyobrażenia muszą być stosowane, ponieważ nie dysponujemy innym językiem do opisu rezultatów doświadczenia. Heisenberg pisał, że fizycy:

mówiąc o procesach atomowych zadowalają się często językiem niedokładnym i metaforycznym, starając się tylko, jak poeci, wywołać w umyśle słuchającego, obrazem i metaforą, pewne poruszenia kierujące się w zamierzonym kierunku, ale nie siląc się do zmuszania go przez jednoznaczne sformułowanie, aby odtwarzał precyzyjnie określony bieg myśli. Jednoznaczny staje się sposób mówienia, gdy posługują się sztucznym językiem matematycznym, o którego poprawności nie można już zebranych doświadczeń, powątpiewać ${ }^{29}$.

Na przykład przy analizie eksperymentu na dwóch szczelinach posługujemy się mechanicznym wyobrażeniem fal, które interferują z sobą, chociaż wiadomo, że nie są to trójwymiarowe fale materii w przestrzeni fizycznej (jak rzecz niegdyś interpretował de Broglie), ale abstrakcyjne „fale prawdopodobieństwa”.

Wyobrażenie eteru istotnie zniknęło ze świata fizyki i można zgodzić się z Sadym, że dla fizyka współczesnego dyskusje nad właściwościami eteru, którym fizycy XX wieku poświęcili tak wiele uwagi, są zupełnie bez znaczenia i okazują się jedynie owocem historycznych uwarunkowań stylu myślowego, jaki panował wśród ówczesnych uczonych ${ }^{30}$. Jednak wyobrażeń cząstek i fal nie da się usunąć z fizycznego obrazu świata, a przynajmniej nie udało się ich wyeliminować przez ostatnie sto lat. Równania (abstrakcyjny formalizm matematyczny mechaniki kwantowej) „działają” znakomicie, ale fizycy nie porzucili prób tworzenia nowych interpretacji mechaniki kwantowej. W fizyce najnowszej przejawia się zatem nie tyle „starcie matematyki z wyobraźnią"31, ile próba uchwycenia dziwności świata kwantów za pomocą wyobrażeniowych modeli.

Struktura dotyczy rewolucji relatywistycznej i kwantowej, a ściślej rzecz bioracc przemian pojęciowych związanych z powstaniem tak zwanej starszej teorii kwantów. O powstaniu współczesnej mechaniki kwantowej Sady wspomina jedynie na kilku stronach $^{32}$. Sam Autor przyznaje, że czytelnik może czuć się nieco rozczarowany ${ }^{33}$. Oczywiście praca Sadego dotyczy jedynie pewnego dobrze wyodrębnionego etapu ewolucji fizyki, który jest przedstawiony niezmiernie szczegółowo i bez „wymyślania historii wstecz", które istotnie pojawiają się często w opracowaniach o charakterze popularnonaukowym. Jednak twierdzenie, że rozważania o przemianach po-

\footnotetext{
28 R. Feynman, Charakter praw fizycznych, tłum. P. Amsterdamski, Warszawa 2000, s. 135-136.

29 W. Heisenberg, Ponad granicami, tłum. K. Wolicki, Warszawa 1979, s. 157.

30 Por. W. Sady, Struktura rewolucji relatywistycznej i kwantowej $w$ fizyce, s. 107.

31 Por. ibidem, s. 106.

32 Por. ibidem, s. 203-206.

33 Por. ibidem, s. 203.
} 
jęciowych, jakie nastąpiły w związku z powstaniem mechaniki kwantowej „byłyby zupełnie niezrozumiałe dla niefizyków"34, wydaje się mocno przesadzone. Przykładem opracowania zawierającego również późniejsze dzieje mechaniki kwantowej jest klasyczna już (i dość stara - 1966 rok) pozycja Maxa Jammera The Conceptual Development of Quantum Mechanics. Wydaje się jednak, że to właśnie takie zagadnienia, jak dualizm korpuskularno-falowy, nieoznaczoność, superpozycja stanów, kwantowe splątanie, nielokalność czy problem pomiaru, które pojawiły się już po sformułowaniu współczesnej postaci mechaniki kwantowej, stanowią największe wyzwanie dla analiz relacji między rolą matematyki a rolą wyobraźni w rozwoju nauki.

\section{Bibliografia}

Albert Einstein. Pisma filozoficzne, tłum. K. Napiórkowski, S. Butrym (red.), Warszawa 1999.

Cooper L.N., Istota i struktura fizyki, tłum. J. Kozubowski, Z. Majewski, A. Pindor, J. Prochorow, Warszawa 1975.

Einstein A., O metodzie fizyki teoretycznej, [w:] A. Einstein, Jak wyobrażam sobie świat. Przemyślenia i opinie, tłum. T. Lanczewski, Kraków 2017.

Einstein A., Zapiski autobiograficzne, tłum. J. Bieroń, Kraków 1996.

Feynman R., Charakter praw fizycznych, tłum. P. Amsterdamski, Warszawa 2000.

Feynman R.P., Sześć trudniejszych kawałków. Teoria względności Einsteina, symetria i czasoprzestrzeń, tłum. P. Amsterdamski et al., Warszawa 1999.

Fleck L., Enstehung und Enwicklung einer wissenschaflicjen Tatsache: Einführung in der lehre von Denkstil und Denkkolektiv, Basel 1935 (wyd polskie: Powstanie i rozwój faktu naukowego: wprowadzenie do nauki o stylu myślowym i kolektywie myślowym, tłum. M. Tuszkiewicz, Lublin 1986).

Fleck L., Psychosocjologia poznania naukowego. Powstanie i rozwój faktu naukowego praz inne pisma z teorii poznania, tłum. W.A. Niemirski, Z. Cackowski, S. Symotiuk (red.), Lublin 2006.

Heisenberg W., Ponad granicami, tłum. K. Wolicki, Warszawa 1979.

Heller M., Krajewski S., Czy fizyka i matematyka to nauki humanistyczne?, Kraków 2014.

Kuhn T.S., The Structure of Scientific Revolutions, Chicago 1962 (wyd. polskie: Struktura rewolucji naukowych, tłum. H. Ostromęcka, Warszawa 1968).

Odkrycie naukowe i inne zagadnienia współczesnej filozofii nauki. Pamięci Elżbiety Pietruskiej-Madej i Jana Żytkowa, W. Krajewski, W. Strawiński (red.), Warszawa 2003.

Sady W., Ludwik Fleck, https://plato.stanford.edu/entries/fleck/.

Sady W., Struktura rewolucji relatywistycznej i kwantowej w fizyce, Kraków 2020.

Weinberg S., Sen o teorii ostatecznej, tłum. P. Amsterdamski, Warszawa 1994.

34 Ibidem, s. 203. 